\title{
AIR TRANSPORT COMPETITION CHALLENGES
}

\author{
Ružica Škurla Babić ${ }^{1}$, Mirko Tatalović ${ }^{2}$, Jasmin Bajić ${ }^{3}$ \\ 1,2 University of Zagreb, Faculty of Transport and Traffic Sciences, Zagreb, Croatia \\ ${ }^{3}$ Croatia Airlines, Zagreb, Croatia
}

Received 7 March 2017; accepted 2 May 2017

\begin{abstract}
Increased competition within global airline industry initiates consolidation activities on entering into different modes of cooperative arrangements including, franchising, code share agreements, alliances, mergers and acquisitions. Selecting the optimal business model means implementation of sustainable competitive strategy as one of the key airline business challenges. Characteristics and trends in airline competition worldwide were analyzed by using correlation and regression metrics. European air transport competition analyzes include specific Southeast Europe topics. The liberalization of the Croatian air transport market has significantly affected the increase in demand in the international scheduled passenger traffic from the year 2004. Air transport in Croatia is growing much faster compare to the maritime and land transport sectors. A significant structural change in the aviation market due to the strong increase of low-cost carriers share in international scheduled traffic occurs. At the same time, the share of domestic scheduled and charter transportation is stagnating. Croatia Airlines in restructuring process provided in the period 2011 - 2015 recognized necessity to justify market position through optimal network strategy.
\end{abstract}

Keywords: competitive strategy, airline, correlation, regression analysis, Croatia Airlines.

\section{Introduction}

At the beginning of $21^{\text {st }}$ century air transport has grown into one of the world's very important industries. It has brought employment and prosperity to millions of people whilst expanding world trade and increasing the opportunities for travel and tourism. With almost 3.8 billion passengers carried in the year 2016 air transport is global economically vital business, encompassing all subjects of aviation value chain including the aircraft and engine manufacturers, fuel suppliers, airports and air traffic control systems. Civil aviation customers are involved in all world economy sectors and segments of the world's population.
The current state of the aviation market is characterized by the presence of very strong competition and rapid changes made by forces of deregulation, fast technology improvements, industry consolidation and innovations. In such competitive environment airlines that can quickly and effectively adapt and change on the market take advantage which is key to winning in the high competitive arena. The paper focuses on competitive strategy and how a company can achieve and sustain competitive advantage. The aim of this paper is to highlight the dynamics and stratification of competition in the global aviation market, and especially in Europe and Croatia. The airlines used for this purpose benchmarking as a tool to

\footnotetext{
${ }^{1}$ Corresponding author: rskurla@fpz.hr
} 
support continuous improvement in order to recognize the shortcomings and advantages over the competition.

\section{Sustainable Competitive Strategy}

From the investors perspective creation and implementation of sustainable competitive strategy is one of the key airline business challenges. According to International Civil Aviation Organization (ICAO) the changing structure of the airline industry will promote cost reduction, better services and traffic growth. The structure of the airline industry will continue to change in three ways (ICAO, 2013):

- Through corporate mergers and acquisition;

- Through divestitures, outsourcing and spin-offs; and

- Through strategic alliances.

Authors and researchers often emphasize cyclical nature of the airline industry, and the fact that the industry as a whole has generally performed poorly when it comes to the profitability level (Baroux, 2013; Clark, 2010; Doganis, 2010; Pilarski, 2007; Tatalović et al., 2012b). Although some airlines have been consistently profitable, airline industry is perceived as being too risky and many investors are now reluctant to direct funds into the airline industry (ICAO, 2013). Therefore, it is important to recognize four main benefits of increased effective competition within the industry (Whish and Bailey, 2012):

- Competition promotes allocative and productive efficiency;

- Competition leads to lower prices for consumers;
- Competition stimulate innovation in order to have better product and win business;

- Competition allows consumers to have a choice of the products they are willing to buy.

All activities are necessary since the aviation industry is highly competitive and price driven, services offered by the air transport industry are very attractive, such that demand can remain resilient even during economic downturns (Palling et al., 2014). In 2011 International Air Transport Association (IATA) worked with Harvard's Professor Michael Porter to look at well-known 5-forces model which include rivalry among existing competitors, the threat of new entrants, the threat of substitute products, the bargaining power of customers and the bargaining power of suppliers. He concluded that there were few industries where the " 5 -forces" were as strong as in the airline industry. It should be noted that level of power is dominantly high but is also medium and rising characteristics as follows (Pearce, 2013):

- The bargaining power of suppliers is high, with powerful labor unions especially at hub operations, concentrated oligopolies in aircraft and engine manufacturing, local monopolies at airports and increasing concentration in the supply of services;

- The bargaining power of the global distribution systems (GDS) is very high, since each of the major GDSs is insulated from competition by their market power;

- Buyer bargaining power is also high, largely because of the perceived commoditization of air travel and low switching costs; 
- The threat of substitute services is medium and rising, with improving technology for web-conferencing and competition from high speed rail on short haul markets;

- The threat of new entrants is high, with easy entry into many markets, easy access to distribution channels and limited incumbency advantages;

- Rivalry among existing competitors is high, partly because of the economics (high sunk costs per aircraft, low marginal cost per passenger, perishable product, and limited economies of scale) but also because of government constraints restricting consolidation through exit or cross border merger. Also because indirect distribution channels currently encourage commoditization and competition on price and schedule alone.

Most companies present in the market perceived as a threat to competitors. By focusing on gaining a larger market share as compared to them and to prevent their entry into the market, they are treated as enemies. However, although competitors are certainly a threat, a healthy competitive environment in air transport may strengthen rather than weaken the competitive position of the airlines (Porter, 2007). Low cost and innovative product differentiation according (Abeyratne, 2016) are two key drivers of competitive strategy that ensure a competitive edge and position among others in the industry. Competition stimulates future market development. But, airlines have to find optimal way how to fight and how to attack competitors. The airline is abandoning the individual market segments in the following cases (Porter, 2007):
- Acquire too small number of advantages in comparison to other segments;

- Change the overall strategy of services;

- Structural segment unattractiveness segment (e.g., charter);

- Potential sales and growth restrictions;

- Limitation of blocking a competitor (Croatia Airlines limited the number of announced Turkish Airlines frequencies during the winter flight schedule (2011/2012) due to limited demand, based on bilateral air transport agreements between the Turkey and Croatia).

However, author McGrath in her book "The End of Competitive Advantage" highlights that businesses are competing in increasingly volatile and uncertain global situations. That suggests that "stability, not change, is the state that is most dangerous in dynamic competitive environments" (McGrath, 2013), and argues "that the end of competitive advantage means that the assumptions that underpin much of what we used to believe about running organizations are deeply flawed" (McGrath, 2013). Besides, (Truxsal, 2013) emphasizes that the "United States and European approaches to market regulation and workable competition are divergent. American firms are permitted to compete aggressively, whereas European firms are expected to maintain competition on certain relevant markets and generally to deal with rivals. Although a firm in position of dominance in a market seems unimportant for either system of market regulation, firm's distorting of competition through any prohibited behaviors will constitute a breach under EU law but not necessarily under US law".

Besides, author (Taneja, 2016b) particularly emphasizes the importance of e-Commerce digital system, along with a digital hub- 
and-spoke system, which supports a tightly integrated marketing capability that will enable an airline to react quickly and effectively according to customer needs in real time. E-Commerce strategy means much more intensive use social network platforms i.e. Facebook, Twitter, You Tube, Google+, LinkedIn, Instagram, etc. Leading active airlines on Facebook are Qatar (10.4 millions), KLM (9.9 millions), Turkish Airlines, Air France, Southwest, etc. On Twitter leading airlines are KLM, JetBlue, Southwest, Air Asia, Philippine Airlines and American Airlines. The most popular airlines on Google+ are KLM, Emirates, Virgin America, British Airways, Delta and Turkish Airlines (Henke, 2016). In that context "Big Data" technologies as a resource and a tool allows airlines personalized approach to customer relations management processes (Mayer-Shonberger and Cukier, 2014).

As well as airlines aircraft and engine manufacturers must contribute to increasing of competition power introducing environmental requirements and impacts that can be define as (Palling et al., 2014):

- Investing in research to design more fuel efficient and environmentally friendly aircraft;

- Managing and optimizing their supply chain;

- Managing, optimizing and innovating the manufacturing process;

- Optimizing aircraft operations and maintenance cycles;

- Inventing new best practices for recycling end-of-life aircraft.

When it comes to airline competition, it should be borne in mind that the forms of competition in the market multilayer include:
- Airlines within the same alliance and code share partners (at the same time competitors);

- Airlines of other alliances;

- Other "Full Service Network Carriers" (FSNC);

- Low cost carriers (LCC);

- Charter carriers;

- Inland transport modes.

All these forms of competition are in parallel and continuous progress, increasing the importance of quality business adjustments. Many leading airlines were faced with the failure of the business problems of survival and growth in a changing market environment (Swissair, Sabena, United, American Airlines, Delta, SAS, Air France, etc.). Such companies are victims of their own success. They've been so successful and they assume they've found the winning formulas, but these same formulas become rigid and no longer work when the market changes significantly (Sull, 2005). Same mistakes made also smaller European airlines like Spanair, Sky Europe, Sterling, Cimber Sterling, Malev, Estonian, Czech Airlines, Air Malta, Cyprus, etc. Together with the speed of market changes airlines need to focus on their business model which is driven by (Whyte and Lohmann, 2017): low cost carriers market share increase, reducing dominantly non-fuel costs, more and more restrictive state aid regulations, yields decrease, product changes and innovations etc.

\section{Characteristics and Trends in Airline Competition Worldwide}

Some 1,400 airlines around the world operate a total fleet of over 26,000 aircraft. They serve 3,880 airports (41,788 airfields) through a route network of several million kilometers managed by about 173 air 
navigation service providers. (ATAG, 2016). The air transport industry generates a total of 62.7 million jobs globally, through direct, indirect, induced and catalytic impacts. Direct jobs represent 9.9 million employees. Indirect jobs represent 11.2 million employees through purchases of goods and services in its supply chain. Induced jobs represent 5.2 million through spending by industry employees. Jobs through air transport's catalytic impact on tourism represent 36.3 million people. Aviation's global economic impact (direct, indirect, induced and catalytic) is estimated at USD 2,700 billion, equivalent to $3.5 \%$ of world Gross Domestic Product - GDP (ATAG, 2016).
Performance indicators can be considered from different points of view which are: operational, technical / technological, institutional, environmental, economic and social (Janjic, 2007). They are all exposed to different levels of competition. Air transport cyclical downturns have almost always been linked to economic cycles. At the same time airline industry has also been affected by other significant factors, most notably several oil crises, Gulf war crisis and Asian crisis. In the new century it was followed by September $11^{\text {th }} 2001$ terrorist attacks in USA and SARS (Severe Acute Respiratory Syndrome) epidemic in Asia during the year 2003 which had tremendously negative impact on the airline profitability (Table 1).

Table 1

Selected Airline Performance Indicators 2000-2015

\begin{tabular}{|c|c|c|c|c|c|c|c|c|c|c|c|c|c|c|c|c|c|}
\hline Worldwide airline industry & 2000 & 2001 & 2002 & 2003 & 2004 & 2005 & 2006 & 2007 & 2008 & 2009 & 2010 & 2011 & 2012 & 2013 & 2014 & 2015 & AAGR* \\
\hline REVENUES, $\$$, billion & 329 & 307 & 306 & 322 & 379 & 413 & 465 & 510 & 570 & 476 & 564 & 642 & 706 & 720 & 751 & 718 & $5.3 \%$ \\
\hline Passenger, \$ billion & 256 & 239 & 238 & 249 & 294 & 323 & 365 & 399 & 444 & 374 & 445 & 512 & 531 & 539 & 539 & 518 & $4.8 \%$ \\
\hline Cargo, $\$$ billion & 40 & 39 & 38 & 40 & 47 & 47.9 & 53.2 & 58.8 & 62.6 & 48.4 & 66.1 & 66.9 & 63.5 & 60.7 & 62.5 & 52.8 & $1.9 \%$ \\
\hline Sched passenger numbers, millions & 1,672 & 1,640 & 1,665 & 1,764 & 1,975 & 2,139 & 2,258 & 2,456 & 2,493 & 2,483 & 2,700 & 2,864 & 2,999 & 3,152 & 3,328 & 3,568 & $5.2 \%$ \\
\hline Freight tonnes, millions & 30.4 & 28.8 & 31.4 & 33.5 & 36.2 & 40.8 & 43.4 & 45.4 & 45.1 & 41.1 & 49.1 & 49.3 & 48.8 & 49.5 & 51.5 & 52.2 & $3.7 \%$ \\
\hline World economic growth, \% & 4.7 & 2.2 & 2.7 & 2.8 & 4.0 & 3.5 & 4.0 & 4.0 & 1.5 & -2.0 & 4.1 & 2.9 & 2.4 & 2.5 & 2.7 & 2.6 & - \\
\hline EXPENSES, $\$$ billion & 318 & 319 & 311 & 323 & 376 & 409 & 450 & 490 & 571 & 474 & 536 & 623 & 687 & 695 & 716 & 659 & $5.0 \%$ \\
\hline Fuel, \$ billion & 46 & 43 & 40 & 44 & 65 & 91 & 127 & 146 & 203 & 134 & 151 & 191 & 228 & 231 & 224 & 180 & $9.5 \%$ \\
\hline Crude oil price, Brent, $\$ / b$ & 28.8 & 24.7 & 25.1 & 28.8 & 38.3 & 54.5 & 65.1 & 73.0 & 99.0 & 62.0 & 79.4 & 111.2 & 111.8 & 108.8 & 99.9 & 53.9 & $4.3 \%$ \\
\hline Flights, million & 21.0 & 21.5 & 20.0 & 21.5 & 23.8 & 24.9 & 25.5 & 26.7 & 26.5 & 25.9 & 27.8 & 30.1 & 31.2 & 32.0 & 33.0 & 34.8 & $3.4 \%$ \\
\hline Break-even weight load factor, \% & 60.8 & 61.3 & 63.2 & 62.3 & 60.9 & 61.2 & 60.7 & 60.3 & 62.2 & 61.8 & 63.5 & 64.1 & 64.7 & 64.5 & 63.9 & 61.3 & $0.1 \%$ \\
\hline Weight load factor achieved, (WLF) $\%$ & 61.5 & 59.0 & 60.9 & 60.8 & 61.5 & 61.8 & 62.7 & 62.7 & 62.1 & 62.0 & 66.8 & 66.1 & 66.4 & 66.8 & 67.0 & 66.9 & $0.6 \%$ \\
\hline Passenger load factor achieed, (PLF) \% & 71 & 69 & 71 & 71 & 73.5 & 75.0 & 76.1 & 77.1 & 76.1 & 76.2 & 78.7 & 78.5 & 79.4 & 79.7 & 79.9 & 80.4 & $0.8 \%$ \\
\hline OPERATING PROFIT, \$ billion & 10.7 & -11.8 & -4.8 & -1.4 & 3.3 & 4.4 & 15.0 & 19.9 & -1.1 & 1.9 & 27.6 & 19.8 & 18.4 & 25.3 & 35.1 & 59.5 & - \\
\hline$\%$ margin & 3.3 & -3.8 & -1.6 & -0.4 & 0.9 & 1.1 & 3.2 & 3.9 & -0.2 & 0.4 & 4.9 & 3.1 & 2.6 & 3.5 & 4.7 & 8.3 & - \\
\hline NET PROFIT, $\$$ billion & 3.7 & -13.0 & -11.3 & -7.5 & -5.6 & -4.1 & 5.0 & 14.7 & -26.1 & -4.6 & 17.3 & 8.3 & 9.2 & 10.7 & 13.7 & 35.3 & - \\
\hline$\%$ margin & 1.1 & -4.2 & -3.7 & -2.3 & -1.5 & -1.0 & 1.1 & 2.9 & -4.6 & -1.0 & 3.1 & 1.3 & 1.3 & 1.5 & 1.8 & 4.9 & - \\
\hline per departing passenger, $\$$ & 2.21 & -7.93 & -6.79 & -4.25 & -2.82 & -1.92 & 2.21 & 5.98 & -10.47 & -1.85 & 6.41 & 2.90 & 3.07 & 3.40 & 4.12 & 9.89 & - \\
\hline RETURN ON INVESTED CAPITAL, \% & 5.0 & 0.2 & 1.1 & 1.7 & 2.9 & 3.3 & 4.7 & 5.7 & 1.3 & 1.9 & 6.2 & 4.7 & 4.6 & 4.8 & 5.9 & 9.3 & - \\
\hline
\end{tabular}
AAGR* - Annual Average Growth Rate

Source: According IATA $(2014,2016)$ prepared and modified by authors.

First decade of a 21st century (2000-2009) saw huge amount of net losses with seven negative financial years and only three positive annual achievements. In spite of average annual economic growth rate of $2.7 \%$, it is fact that growth rate of expenses (4.5\%) was faster compared to growth rates of revenues $(4.2 \%)$ which generated net loss of 48.8 billion USD. But from the year 2010 airlines recovered generating to the year 2015 net profit of 94.5 billion USD, dominantly due to achieved WLF higher of $66 \%$ and PLF higher of $78 \%$. At the same time labor productivity for the whole period 2000-2015 increased with average annual growth rate of $3.9 \%$. Best business year is 2015 with net profit 35.3 billion USD and the worst business year was 2008 with net losses of 26.1 billion USD due to high jet fuel prices and global economic crisis. In 
whole period 2000-2015 airline industry generated net profit of 45.7 billion USD which looks healthy but achieved net profit margin was only $0.6 \%$. Interesting fact is that net profit per departing passenger is only 1.17 USD, equivalent to only one espresso coffee in Croatia (limited number of coffee shops). That leads to the serious question: Does it make sense to fight on the aviation market? Overall financial results would be worst without government capital injections and aids like United States 15 billion USD package consisting of a 5 billion USD cash payment to the industry and 10 billion USD in guaranteed loans plus 3 billion USD in security costs not included in the cash grant or loans (Dizikes and Valenti, 2001).

The biggest contributions to evolving air competition worldwide according to (Taneja, 2017) are:

1. Expansion of Persian Gulf FSNC airlines so called Super Connectors (Turkish, Emirates, Qatar, Etihad) with impressive examples of Emirates connecting in year 2005 ten airports in Africa with 23 airports in the AsiaPacific region progressing to 20 African airports with 40 markets in the AsiaPacific in the year 2015; Cost structure of Emirates (US cents per available seat kilometres) is more favorable i.e. lower unit cost compared to British Airways and Virgin Atlantic despite the higher average stage length of Virgin (Taneja, 2016a).

2. Expansion of the LCC visible from the fact that LCC started to offer scheduled service in intercontinental market (Air Asia X, Air Berlin, Cebu Pacific, Icelandair, Flynas, Jetstar, Norwegian).
E-Commerce significantly contributes to airline ancillary revenue level and importance. In the year 2015 ancillary revenue was realized on the level of 59.2 billion USD (8.2 percent of total airline) revenues (IdeaWorksCompany, 2016b). Top ten carriers worldwide achieved more than billion USD of ancillary revenue leading by United (6.2 billion USD) followed by American (4.7 billion USD) and Delta (3.8 million USD). Using criteria ancillary revenue as a percent of total revenue leading airlines are LCCs Spirit (43.4 percent), Allegiant (37.6 percent) and Wizz Air with share of 36.4 percent (IdeaWorksCompany, 2016a).

In an attempt to answer on causes and consequences of the airline competition one of the most interesting items is the correlation between natural and economic productivity measures. A simple linear correlation coefficient is a numeric expression by which rate and direction of two phenomenon link, which are in linear statistical relation, is measured. Pearson correlation coefficient " $r$ " is a measure of the linear correlation of two variables as it is shown in eq. 1 (Black, 2010):

$r=\frac{\Sigma(x-\bar{x})(y-\bar{y})}{\sqrt{\Sigma(x-\bar{x})^{2} \Sigma(y-\bar{y})^{2}}}=\frac{\Sigma x y-\frac{(\Sigma x \Sigma y)}{n}}{\sqrt{\left[\Sigma x^{2}-\frac{(\Sigma x)^{2}}{n}\right]\left[\Sigma y^{2}-\frac{(\Sigma y)^{2}}{n}\right]}}$

Specifically, the correlation analysis for the period 1991 - 2015 (from the year 1991 Croatia Airlines was starting operation) identifies a strong correlation of natural productivity indicators, i.e. weight load factor and tone kilometers (RTK) per employee (0.898), regarding the revenue level (WLF - revenues 0.946, RTK per 
employee - revenues 0.949). There is weaker correlation regarding the WLF and operating result $(0.748)$ and RTK per employee versus operating result (0.552). Similar are the results of covariance regarding the correlation of WLF versus net profit (0.527), while the weakest indicator is RTK per employee versus net profit (0.301).
Taking into consideration above mentioned indicators, it should be emphasized that the Pearson's correlation coefficient results of Croatia Airlines are not identical to worldwide airlines achievements since the correlation of productivity indicators vs. operating result and profit/loss does almost not exist.

\section{Table 2}

Correlation Results $1991-2015$

\begin{tabular}{|l|c|c|c|c|c|c|c||}
\hline & $\begin{array}{c}\text { WLF - } \\
\text { RTK/Employee }\end{array}$ & $\begin{array}{c}\text { WLF - } \\
\text { Revenue }\end{array}$ & $\begin{array}{c}\text { WLF - Operating } \\
\text { result }\end{array}$ & $\begin{array}{c}\text { WLF - } \\
\text { Profit/Loss }\end{array}$ & $\begin{array}{c}\text { RTK/Employee } \\
\text { Revenue }\end{array}$ & $\begin{array}{c}\text { RTK/Employee } \\
\text { Oper. result }\end{array}$ & $\begin{array}{c}\text { RTK/Employee } \\
\text { - Profit/Loss }\end{array}$ \\
\hline Croatia Airlines & 0.949 & 0.870 & -0.025 & 0.141 & 0.849 & -0.072 & 0.192 \\
\hline World Aviation & 0.898 & 0.946 & 0.748 & 0.527 & 0.949 & 0.552 & 0.301 \\
\hline
\end{tabular}

Source: Based on data from previous authors research (Bajić, et al., 2016), IATA $(2014,2016)$ and internal Croatia Airlines data.

In the world professional and scientific literature, the airline industry is a good example of the power of price signaling when prices typically rise and fall depending on the current state of customer demand. In that context authors (Hill et al., 2015) emphasize that if one carrier signals the intention to lower prices, a price war frequently ensues as other carriers copy each other's signals. If one carrier feels demand is strong, it tests the waters by signaling an intention to increase prices, and price signaling becomes a strategy to obtain uniform price increases. Analyzing data from Table 1 it can be concluded that the average passenger fare in the period 2011-2015 is falling from 178.8 USD to 145.2 USD per passenger carried (annual average growth rate $-5.1 \%$ ).

\section{European Air Transport Competition}

Air transport plays a vital role in the European economy and for international trade. This industry generates 2.5 million employees and accounts for more than $26 \%$ of worldwide air transport. Including indirect, induced and catalytic impacts the air transport industry generates almost 12 million jobs in Europe and contributes more than USD 860 billion to European gross domestic product - GDP (ATAG, 2016). The European civil aviation market is highly developed, since 181 European airlines is operating on the 580 airports carrying 530 million passengers (Tatalović et al., $2012 b$ ). It is an opportunity for industry and consumers, especially because Europe is a leading worldwide tourism region.

At the same time, high-speed trains and modern highways increasingly compete with air transport in Europe. The tunnel under the English Channel generated over 7 million passengers a year $2004^{\text {th }}$, on London-Paris and London-Brussels (Mišetić et al., 2007). It is important to highlight that in Europe, short-haul airlines face serious competition from surface transport (growing high-speed rail network), while US airlines do not generally face such competition (Gittell et al., 2016). In Europe a significant number of airlines were owned or subsidized by the state as a necessary instrument of economic 
development. The level of direct state aid to selected European airlines to carry out the privatization process in the period 1991-2005 seven leading European airlines amounted to 19.4 billion USD (Tatalović et al., 2012b). During the 2015 the capacity share on the European market (Fig. 1) changed in flavor of LCC reaching $36 \%$. In the year 2003 the structure of market share was completely different i.e. $71 \%$ FSNC, $12 \%$ LCC, $8 \%$ charter and $9 \%$ regional carriers (Tatalović, et al., 2012b). Therefore, European full service network carriers are facing strong competition from LCC airlines mainly on intra-European routes and additional big competition challenge are the growing airlines from the Middle East. In such market environment European airline landscape is on process of consolidation. Three big airline groups consist of the strongest players formed by the merger (British Airways \& Iberia - IAG, Air France / KLM) and acquisitions (Lufthansa Group - Swiss, Austrian, SN Brussels, Germanwings / Eurowings, Air Dolomiti, etc.). All are in the process of restructuring, reducing the number of employees, and optimizing flight network within Europe (Bajić et al., 2016). In order to fully accommodate the new trends in the European airline market, those airlines should reorganize their structures and change management system at their base airports. Improving efficiency and competitiveness, with flexible use of resources, will enable airlines to have a better cost allocation so that they can have a parallel cost advantage when competing in the global market (Heshmati and Kim, 2016).

Authors Whyte and Lohmann (2017) gave examples of FSNC, cargo and charter airlines which establish an in-house low cost subsidiary or low-cost brand ("carrierwithin-a-carrier" - CWC, or an "airlinewithin-an-airline” - AWA): bmi - bmibaby; British Airways - Go; KLM UK - Buzz; Lufthansa - Germanwings; MyTravel (charter) - MyTravelLite; SAS - Snowflake; Thomson Airways (charter) - ThomsonFly; Channel Express (cargo) - Jet2.

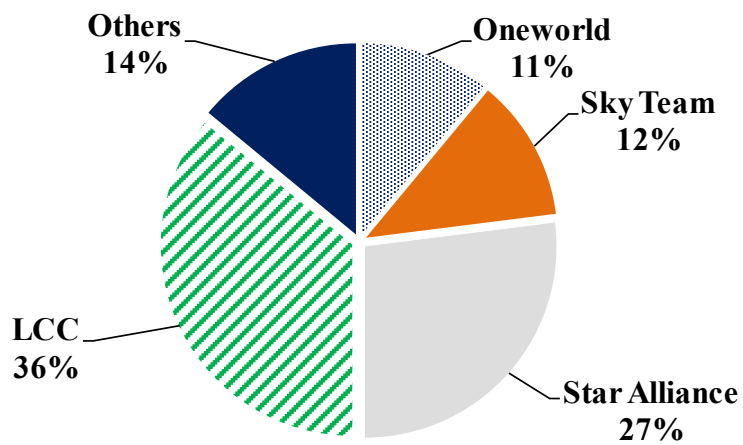

Fig. 1.

Intra-European Air Transport Seats by Alliance Source: capstats.com (2015).

From the point of view of European financial and economic results during the period 2006-2015 only two business years could

be remarked as very successful. In general net profit and earnings before interest and taxes (EBIT) margin are relatively weak 
(Fig. 2). Profit per carried passenger in the best year (2015) was 8.11 USD compared to 9.89 USD worldwide.

Breakeven load factors are highest in Europe, caused by low yields due to the competitive open aviation area, and high regulatory costs. Growth in this region was damaged by terrorist attacks, but a modest rebound is anticipated next year. Forecast of net profit for the year 2017 shows fall to 5.6 billion USD representing 5.65 USD per passenger and a margin of 2.9 percent (IATA, 2016).

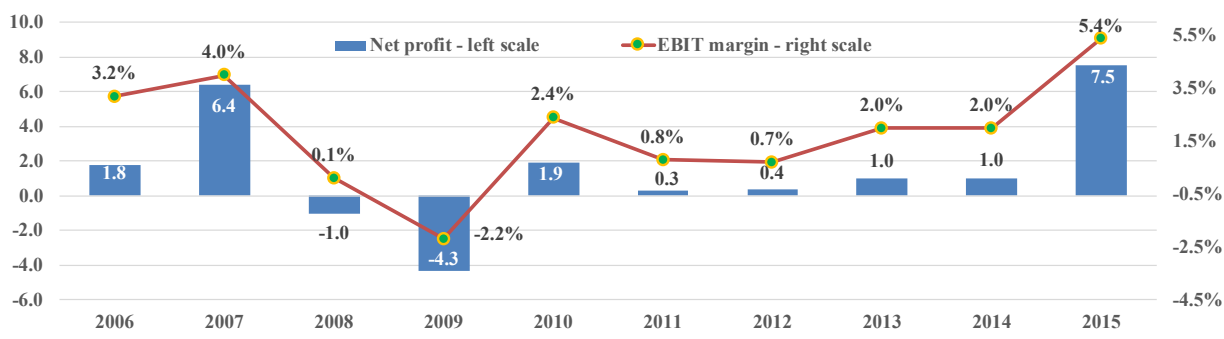

Fig. 2.

European Airlines Net Profit and EBIT Margin in the Period 2006-2015

Source: IATA (2016), prepared by authors.

Southeast Europe region over the last 25 years have passed violently through a period marked by war events, global and regional economic crisis of different magnitudes and more or less successful transition processes. Defining the region with total 11 countries (Albania, Bosnia and Herzegovina, Croatia, FYR Macedonia, Montenegro, Serbia, Kosovo*, Romania, Bulgaria, Moldova and Slovenia) i.e. without Greek and Turkey intention is to emphasize and differentiate the level of air transport market development indicators (Bajić et al., 2016). (Steiner et al., 2010) have emphasized that creating a single European market, more than 58 million people and 30 airports of the Southeast Europe region would be fully integrated consisting thus market for 500 million people in total. In order to improve procompetitive efficiency in this process the airlines of Southeast Europe should segment their market properly, avoiding the mistakes of both over and under-segmentation, and build a sound understanding of the needs of their customers in each of the market segments (Shaw, 2011) At the same time standard of living in the region points to the need of avoiding influence of exogenous factors (cyclicality, ease of access to capital, cost of aircraft, competition, consolidation, etc.) and endogenous factors (labor, management, pricing, etc.) to generate losses in aviation sector (Pilarski, 2007). Possible implementation of "Public Service Obligation" model within the region would increase economic activities level among the Southeast Europe region countries, leading to economic development and progress, political stability, continuation of the European integrations (Tatalović, et al., 2014).

It is also important to be aware of the LCC penetration in the Southeast Europe due to competition challenges with network carriers based in the region (Table 3 ). 
Table 3

LCCs on SEE Region Airports (Summer Timetable 2012)

\begin{tabular}{|c|c|c|c|c|c|c|c|c|c|c|c|c|c|c|c|c|c|c|c|c|c|c|c|c|c|c|c|c|c|}
\hline Airport & 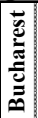 & $\left\{\begin{array}{l}0 \\
\frac{\pi}{5} \\
\frac{5}{5} \\
0\end{array}\right.$ & 竎 & 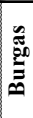 & 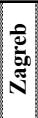 & $\stackrel{\Xi}{\underset{\Xi}{\Xi}}$ & 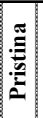 & $=$ & 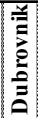 & 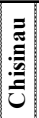 & : & $\stackrel{\pi}{\pi}$ & $\Xi$ & $\mid \begin{array}{c}\frac{0}{2} \\
\frac{\hat{\sigma}}{\omega}\end{array}$ & 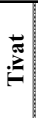 & 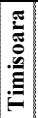 & $\frac{0}{\sqrt{\pi}}$ & $\frac{\pi}{\Xi}$ & 㬕 & 站 & $\stackrel{\pi}{\square}$ & : & $\frac{3}{3}$ & $\frac{\pi}{4}$ & $\frac{3}{0}$ & 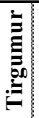 & & 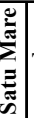 & Total \\
\hline Ryanair - FR & & & & & & & & & & & & & & & & & & 1 & 1 & 1 & 1 & 1 & 1 & & & & & & 6 \\
\hline Easyjet - GO & & & 1 & & 1 & & 1 & 1 & 1 & & 1 & & & & & & & & & & & & & & & & & & 6 \\
\hline Air Berlin - AB & 1 & 1 & 1 & & & & 1 & 1 & . & & & & & 1 & 1 & & & 1 & 1 & 1 & & & & 1 & & & & & 11 \\
\hline Norwegian - DY & & 1 & & 1 & 1 & & 1 & 1 & 1 & & & 1 & & & & & 1 & 1 & & & 1 & & & & 1 & & & & 11 \\
\hline Vueling - VY & 1 & & & & 1 & & & 1 & 1 & & & & & & & & 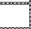 & 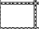 & 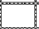 & & & & & & & & & & 4 \\
\hline Wizzair -W6 & 1 & 1 & 1 & 1 & & & & 1 & & & 1 & 1 & 1 & 1 & & 1 & & & & & & & & & & 1 & & & 11 \\
\hline Aer Lingus - EI & 1 & & & 1 & & & & & 1 & & & & & & & & & & & & & & & & & & & & 3 \\
\hline Germanwings - 4U & 1 & 1 & & & 1 & 1 & 1 & 1 & 1 & & & & & & & & 1 & 1 & 1 & & 1 & & & & & & & & 11 \\
\hline flybe - BE & & & & & & & & & 1 & & & & & & & & & & & & & & & & & & & & 1 \\
\hline Transavia-HV & & & & 1 & & & & 1 & 1 & & & & & & & & & & & & & & & & & & & & 3 \\
\hline Jet2 - LS & & & & & & & & 1 & 1 & & & & & & & & & 1 & & & & & & & & & & & 3 \\
\hline bmibaby - WW & & & & & & & & & 1 & & & & & & & & & & & & & & & & & & & & 1 \\
\hline Air Baltic - BT & & & & & & & & & & 1 & & & & & & & & & & & & & & & & & & & 1 \\
\hline Windjet - IV & 1 & & & & & & & & & & & & & & & & & & & & & & & & & & & & 1 \\
\hline Blue Air 0B & 1 & & & & & & & & & & & & 1 & & & & & & & & & & & & 1 & & 1 & 1 & 5 \\
\hline Total & 7 & 4 & 3 & 4 & 4 & 1 & 4 & 8 & 9 & 1 & 2 & 2 & 2 & 2 & 1 & 1 & 2 & 5 & 3 & 2 & 3 & 1 & 1 & 1 & 2 & 1 & 1 & 1 & 78 \\
\hline
\end{tabular}

Source: According to Bjelicic (2013), prepared by authors.

After the year 2012 expansion of LCC in the Southeast Europe intensifies. The best example is airport Tuzla (Wizzair) with extremely high annual average growth rate of passenger traffic in the period 2012-2016 (311.398 passengers) of 194 percent (www. tuzla-airport.ba, 2017). The analysis of airport competition challenges in the Southeast Europe region is also very interesting. Namely the level of passengers on above mentioned 11 countries airports is $40-45$ million. In Table 4 is the list of biggest airports in the region measured by criteria annual passengers' number higher than 500 thousand.

\section{Table 4}

Passengers on Dominant Airports in the SEE Region 2006-2015

\begin{tabular}{|c|c|c|c|c|c|c|c|c|c|c|c|c|}
\hline \multirow{2}{*}{ Airport } & \multicolumn{10}{|c|}{ Passengers } & \multirow{2}{*}{$\begin{array}{c}\text { AAGR } \\
\%\end{array}$} & \multirow{2}{*}{$\begin{array}{c}\text { Runaway } \\
\text { (m) }\end{array}$} \\
\hline & 2006 & 2007 & 2008 & 2009 & 2010 & 2011 & 2012 & 2013 & 2014 & 2015 & & \\
\hline Bucharest OTP & 3,514 & 4,979 & 5,064 & 4,481 & 4,803 & 5,049 & 7,102 & 7,643 & 8,317 & 9,283 & 11.4 & 3,500 \\
\hline Belgrade & 2,222 & 2,513 & 2,650 & 2,384 & 2,699 & 3,125 & 3,364 & 3,543 & 4,639 & 4,776 & 8.9 & 3,400 \\
\hline $\begin{array}{l}\text { Sofia } \\
\end{array}$ & 2,209 & 2,746 & 3,231 & 3,135 & 3,297 & 3,475 & 3,467 & 3,504 & 3,815 & 4,089 & 7.1 & 3,600 \\
\hline Zagreb & 1,728 & 1,922 & 2,192 & 2,062 & 2,072 & 2,319 & 2,342 & $\mathbf{2 , 3 0 0}$ & 2,431 & 2,588 & 4.6 & 3,252 \\
\hline Bourgas & 1,702 & 1,949 & 1,937 & 1,684 & 1,873 & 2,229 & 2,357 & 2,456 & 2,530 & 2,360 & 3.7 & 3,200 \\
\hline Chisinau & 548 & 689 & 848 & 809 & 938 & 1,044 & 1,221 & 1,321 & 1,781 & 2,219 & 16.8 & 3,590 \\
\hline Tirana & 906 & 1,107 & 1,267 & 1,395 & 1,537 & 1,817 & 1,665 & 1,757 & 1,810 & 1,977 & 9.1 & 2,750 \\
\hline Split & 1,096 & 1,191 & 1,204 & 1,115 & 1,220 & 1,300 & 1,426 & 1,582 & 1,753 & 1,955 & 6.6 & 2,550 \\
\hline Dubrovnik & 1,120 & 1,143 & 1,191 & 1,122 & 1,270 & 1,350 & 1,480 & 1,523 & 1,584 & 1,694 & 4.7 & 3,300 \\
\hline Pristina & 883 & 990 & 1,131 & 1,192 & 1,306 & 1,422 & 1,527 & 1,629 & 1,427 & 1,579 & 6.7 & 2,500 \\
\hline Cluj & 244 & 391 & 753 & 834 & 1,029 & 1,005 & 932 & 1,035 & 1,182 & 1,488 & 22.2 & 2,200 \\
\hline Skopje & 542 & 627 & 652 & 658 & 681 & 760 & 829 & 984 & 1,211 & 1,456 & 11.6 & 2,950 \\
\hline Ljubljana & 1,334 & 1,524 & 1,673 & 1,434 & 1,389 & 1,369 & 1,199 & 1,321 & 1,307 & 1,438 & 0.8 & 3,300 \\
\hline Varna & 1,400 & 1,493 & 1,450 & 1,207 & 1,199 & 1,164 & 1,211 & 1,308 & 1,387 & 1,399 & 0.0 & 2,500 \\
\hline Timisoara & 754 & 837 & 957 & 974 & 1,138 & 1,201 & 1,036 & 757 & 735 & 924 & 2.3 & 3,500 \\
\hline Tivat & 451 & 574 & 568 & 532 & 542 & 647 & 725 & 868 & 911 & 889 & 7.8 & 2,500 \\
\hline Sarajevo & 466 & 505 & 506 & 530 & 563 & 600 & 580 & 666 & 710 & 773 & 5.8 & 2,600 \\
\hline Podgorica & 382 & 460 & 541 & 450 & 652 & 612 & 620 & 681 & 702 & 749 & 7.8 & 2,500 \\
\hline Total & 21,504 & 25,640 & 27,816 & 25,998 & 28,205 & 30,488 & 33,084 & 34,879 & 38,232 & 41,637 & 7.6 & \\
\hline
\end{tabular}

Source: Prepared by authors and based on data: Steiner et al. (2010), anna.aero, (2016). 
Finally, according to the air transport competition challenges in the Southeast Europe Region it is useful to know ranking results of Air Transport Infrastructure from the study "The Travel \& Tourism Competitiveness Report 2015" which includes 141 countries worldwide (Fig. 3). Air Transport Infrastructure is defined and analyzed by six indicators (WEF, 2015): (1) Quality of air transport infrastructure, (2) Airline domestic seat $\mathrm{km}$ per week, (3) Airline international seat km per week, (4) Departures per 1,000 populations, (5) Airport density per million urban populations, (6) Number of operating airlines. The leading country is Canada with value 6.75, followed by United States (5.95).

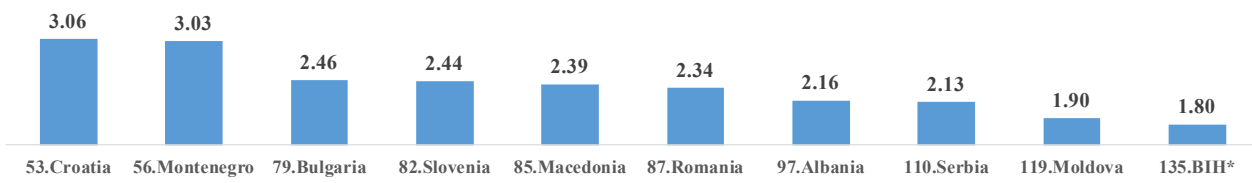

* Bosnia and Herzegovina ranking is from 2013 edition.

Fig. 3.

The Ranking of Individual Southeast Europe Countries by the Efficiency of Air Transport Infrastructure Source: $\operatorname{WEF}(2013,2015)$, prepared by authors.

\section{Croatian Air Transport Market}

In the year 2015 the Croatian economy has started expected recovery $(+1.6 \%$ real GDP growth) after six years of economic crisis followed by negative GDP trends. Relatively dynamic GDP growth of $2.8 \%$ is expected for the year 2016. Macroeconomic indicators of Croatian economy indicate that since year 2008 the level GDP in current prices ( 48.1 billion EUR) declined nine percent to the level of 43.9 billion EUR in the year 2015 (HGK, 2016). The gross foreign debt of Croatia in 2015 amounted to 45.3 billion EUR. In addition, the unemployment rate was 17.4 percent which is lower (20.2 percent) compared to the year 2013 (HGK, 2016). All these facts undoubtedly affect the economics of air transport in Croatia.

However, the economic crisis affected to certain level the Croatian tourism. It should be noted that air transport worldwide is the most important component of the tourist arrivals to their destination. According to The World Tourism Organization (UNWTO) inbound tourism data for the year 2015 by mode of transport shows that 54 percent tourists are using air transportation (UNWTO, 2016).

From the Croatian point of view year 2015 saw natural indicators of 14.3 million tourist arrivals which is the most successful tourist year since Croatian independence (Table 5). 
Table 5

Tourist Arrivals in Croatia from 1985 to 2015

\begin{tabular}{|c|c|c|c|c|c|c|c|c|c|c|c|c|c|c|c|c|}
\hline Tourists (thous and) & 1985 & 1990 & 1995 & 2000 & 2005 & 2006 & 2007 & 2008 & 2009 & 2010 & 2011 & 2012 & 2013 & 2014 & 2015 & $\begin{array}{c}\text { AAGR } \\
05-15\end{array}$ \\
\hline Total Arrivals & 10,125 & 8,497 & 2,610 & 7,137 & 9,995 & 10,385 & 11,162 & 11,261 & 10,935 & 10,604 & 11,456 & 11,835 & 12,434 & 13,128 & 14,343 & $3.7 \%$ \\
\hline Domestic & 2 & $>1$ & 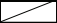 & 3 & 1,528 & 1,726 & 1,856 & 1,846 & 1,600 & 1,493 & 1,529 & 1,466 & 1,486 & 1,505 & 1,660 & $0.8 \%$ \\
\hline International & 2 & C & 5 & $C$ & 8,467 & 8,659 & 9,306 & 9,415 & 9,335 & 9,111 & 9,927 & 10,369 & 10,948 & 11,623 & 12,683 & $4.1 \%$ \\
\hline Germany & 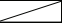 & $C$ & 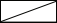 & 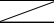 & 1,572 & 1,545 & 1,555 & 1,546 & 1,580 & 1,525 & 1,661 & 1,853 & 1,932 & 1,989 & 2,124 & $3.1 \%$ \\
\hline \begin{tabular}{|l} 
Slovenia \\
\end{tabular} & 3 & 3 & 3 & 7 & 879 & 913 & 1,015 & 1,043 & 1,013 & 1,017 & 1,100 & 1,054 & 1,067 & 1,102 & 1,192 & $3.1 \%$ \\
\hline Austria & 2 & 3 & 3 & 3 & 742 & 790 & 840 & 814 & 882 & 810 & 893 & 946 & 969 & 1,019 & 1,120 & $4.2 \%$ \\
\hline Italy & 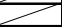 & 7 & 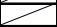 & 7 & 1,253 & 1,235 & 1,249 & 1,168 & 1,200 & 1,018 & 1,150 & 1,051 & 1,017 & 1,061 & 1,111 & $-1.2 \%$ \\
\hline Czech Republic & 2 & 2 & 2 & 3 & 616 & 593 & 669 & 623 & 607 & 606 & 638 & 647 & 652 & 661 & 696 & $1.2 \%$ \\
\hline
\end{tabular}

Source: Croatian Bureau of Statistics (2010, 2014, 2016c), prepared by authors.

In the period 2005-2015 average annual growth rate of total tourist's arrivals was 3.7 percent. Domestic arrivals with growth rate of 0.8 percent are stagnating. It should be emphasized that compared to the year 1985 average annual growth rate is only 1.2 percent. The main reason is visible from the achieved results in the war affected year 1995. From the table 5 is obvious that the prewar level of 10,125 thousand was reached more than twenty years later (2006). Table 5 is also representing top five tourist origin counties.

However, the Croatian aviation market is characterized by international passenger traffic generated by foreigners with more than 87 percent share. That is a significant limiting factor in terms of Croatian carrier's market positioning. According to the Global Competitiveness Index 2016 - 2017 Croatia is on the 74th place with a score of 4.15 out of a total of 138 ranked countries (WEF, 2016). It is necessary to bear in mind that in the period from 2002 to 2015 Croatian positions towards the Global Competitiveness Index of the World Economic Forum dropped from $63^{\text {rd }}$ to $74^{\text {th }}$ (Tatalović et al., 2012a). It should be concluded that the Croatian competitiveness index is rather insufficient and has negative impact on present and future air transport development.

Based on the regression analysis, impact of Croatian real gross domestic product growth on Croatian citizen's demand for the international passenger air traffic gets the following eq. 2 (Bajić et al., 2014):

$\mathrm{Y}=6,414 \%+2,1333^{*} \mathrm{X}$; where $\mathrm{Y}$ is passenger growth; $\mathrm{X}$ is real GDP growth

It can be concluded that increase in real Croatian GDP for 1 percentage point, on average, increases Croatian citizen's demand for international passenger traffic to 2.13 percentage points. The result corresponds with the Airbus research elasticity of demand for passenger air transportation where1 percent increase of GDP influence on demand in the range from +1 to +2.5 percent. Furthermore, it is evident that the growth of international passenger traffic of Croatian citizens in the Croatian aviation market was $6.414 \%$, regardless of the growth of gross domestic product. This is understandable because of Croatian air transport market liberalization process which at the same time further stimulated domestic demand. Based on regression analysis $\mathrm{R}^{2}=72.42 \%$ was obtained, which indicates in this model that $72.42 \%$ deviation of growth of international passenger traffic of Croatian citizens $(\mathrm{Y})$ may interpret as a growth of Croatian gross domestic product (X) (for detailed explanations and implementations of the model results achieved cfr. Bajić, et al., 2014.). 
During the negotiations for the conclusion of "Horizontal Agreement" Croatia has unilaterally committed itself to open its aviation market to all air carriers from the European Union regardless of their nationality and the routes they intend to open. This approach resulted in a rapid increase of international air traffic, in particular the entrance of low-cost carries. These processes were not followed by appropriate strategic decisions of the Croatian government. Such approach has led to a growing number of airline competitors which strengthen the monopoly position of Croatian airports, air traffic control and INA as only supplier of jet fuel. Croatian privately owned charter carriers Air Adriatic and Dubrovnik Airline (2006-2007 transported over 570,000 passengers annually) went bankruptcy. At the same time Croatia Airlines generated significant yield decrease, negative operational and net financial results which jeopardized sustainable business and future development.

Finally, one of the air transport competition challenges is also inland transport modes The structure and dynamics of the passenger transport (Passenger kilometers -RPK) of individual transport modes in Croatia is shown in the Table 6.

Table 6

Structural Changes in Croatian Passenger Transportation 1990 - 2015 (million RPK)

\begin{tabular}{|c|c|c|c|c|c|c|c|c|c|c|c|c|}
\hline Trans port Mode & 1990 & $\begin{array}{c}\text { Share } \\
\%\end{array}$ & 1992 & $\begin{array}{c}\text { Share } \\
\%\end{array}$ & 2000 & \begin{tabular}{|c|} 
Share \\
$\%$
\end{tabular} & 2005 & \begin{tabular}{|c|} 
Share \\
$\%$
\end{tabular} & 2010 & $\begin{array}{c}\text { Share } \\
\%\end{array}$ & 2015 & \begin{tabular}{|c|}
$\begin{array}{c}\text { Share } \\
\%\end{array}$ \\
\end{tabular} \\
\hline Railway Transport & 3,429 & 32 & 981 & 19 & 1,252 & \begin{tabular}{|l|}
22 \\
\end{tabular} & 1,266 & \begin{tabular}{|l|}
18 \\
\end{tabular} & 1,742 & 25 & 951 & \begin{tabular}{|r|}
15 \\
\end{tabular} \\
\hline Road Tra & 7.004 & 66 & 3.731 & 73 & 3.331 & 59 & 3.403 & 48 & 3.284 & 47 & 3.377 & \\
\hline Seawater Transport & 198 & 2 & 261 & 5 & 328 & 6 & 431 & 6 & 493 & 7 & 624 & 10 \\
\hline AirTransport & & 0 & 145 & 3 & 763 & 13 & 1.989 & 28 & 1.510 & 21 & 1.438 & 22 \\
\hline Total & 10,631 & 100 & 5,118 & 100 & 5,674 & 100 & 7,089 & 100 & 7,029 & 100 & 6,390 & 100 \\
\hline
\end{tabular}

Source: According (Bajić et al., 2014) and Croatian Bureau of Statistics $(2015 ; 2016 b)$, prepared by authors.

Table 6 indicates the negative trends of inland transport, since the achieved results in 2015 are practically on the level of the war characterized year of 1992 . The winners are see water (share increase from $4 \%$ to $10 \%$ ) and air transport (close to 10 times higher transport achievement) It should be noted that in 2005 the share of air transport was 28 percent falling to 23 percent in the year 2015 .

\section{Analysis of Croatian Air Transport Competition}

Liberalization of the Croatian air transport market after the year 2003 stimulated expansion of all competition forms so that by 2015 the total number of passengers increased 2.5 times. Domestic scheduled and international charter flights are stagnating while charter Croatian carrier's flights almost disappear. At the same time, international scheduled traffic increased several times (4.9). The number of passengers carried by low-cost carriers (LCC) is growing rapidly and in 2015 reached a share of 38.2 percent of all passengers i.e. 46.5 percent of international scheduled passengers. The Croatia Airlines (CTN) market share of international scheduled passengers was 24 percent in 2015 and total share was 27.7 percent compared to total share of 58.7 percent in the year 2003 (Table 7). 


\section{Table 7}

The Passenger Structure of Croatian Air Transport Market 2003-2015

\begin{tabular}{|c|c|c|c|c|c|c|c|c|c|c|c|c|c|}
\hline Passengers (Thousand) & 2003 & $\%$ & 2008 & $\%$ & 2011 & $\%$ & 2014 & $\%$ & 2015 & $\%$ & $\begin{array}{c}\text { Index } \\
15 / 03\end{array}$ & $\begin{array}{c}\text { Index } \\
15 / 14\end{array}$ & AAGR \\
\hline Domestic Scheduled & 471 & $18.8 \%$ & 543 & $11.5 \%$ & 505 & $9.7 \%$ & 488 & $7.8 \%$ & 474 & $7.1 \%$ & 101 & 97 & $0.1 \%$ \\
\hline International Scheduled LCC & 0 & $0.0 \%$ & 1,106 & $23.5 \%$ & 1,520 & $29.3 \%$ & 2,345 & $37.7 \%$ & 2,547 & $38.2 \%$ & - & 109 & - \\
\hline International Scheduled FSNC & 325 & $13.0 \%$ & 715 & $15.2 \%$ & 1,085 & $20.9 \%$ & 1,504 & $24.2 \%$ & 1,623 & $24.3 \%$ & 499 & 108 & $14.3 \%$ \\
\hline International Scheduled CTN & 796 & $31.9 \%$ & 1,209 & $25.7 \%$ & 1,307 & $25.2 \%$ & 1,280 & $20.6 \%$ & 1,312 & $19.7 \%$ & 165 & 103 & $4.3 \%$ \\
\hline Charter Foreign Carriers & 611 & $24.4 \%$ & 744 & $15.8 \%$ & 502 & $9.7 \%$ & 538 & $8.6 \%$ & 646 & $9.7 \%$ & 106 & 120 & $0.5 \%$ \\
\hline Charter Croatian Carriers & 296 & $11.8 \%$ & 387 & $8.2 \%$ & 266 & $5.1 \%$ & 69 & $1.1 \%$ & 67 & $1.0 \%$ & 23 & 97 & $-12 \%$ \\
\hline Passengers Total & 2,499 & $100 \%$ & 4,704 & $100 \%$ & 5,185 & $100 \%$ & 6,224 & $100 \%$ & 6,669 & $100 \%$ & 267 & 107 & $8.5 \%$ \\
\hline CTN Total & 1,468 & & 1,869 & & 1,879 & & 1,825 & & 1,850 & & 126 & 101 & $1.9 \%$ \\
\hline CTN Share of Total & $58.7 \%$ & & $39.7 \%$ & & $36.2 \%$ & & $29.3 \%$ & & $27.7 \%$ & & 47 & 95 & $-6.1 \%$ \\
\hline Croatian Airports & 2,922 & & 5,179 & & $\mathbf{5 , 5 8 5}$ & & 6,703 & & 7,176 & & 246 & 107 & $7.8 \%$ \\
\hline CTN Share - Croatian Airports & $64.4 \%$ & & $44.5 \%$ & & $42.1 \%$ & & $33.2 \%$ & & $31.2 \%$ & & 48 & 94 & $-5.9 \%$ \\
\hline
\end{tabular}

Source: According (Bajić et al., 2014), Croatian Bureau of Statistics (2015, 2016b), Croatian airports statistics and Croatia Airlines internal data prepared by authors.

Growth generator of international scheduled whose number in the period increased from traffic in the Croatian aviation market for the 9 to 45 and the number of passengers has period 1996-2015 year are foreign carriers increased by more than ten times (Fig. 4).

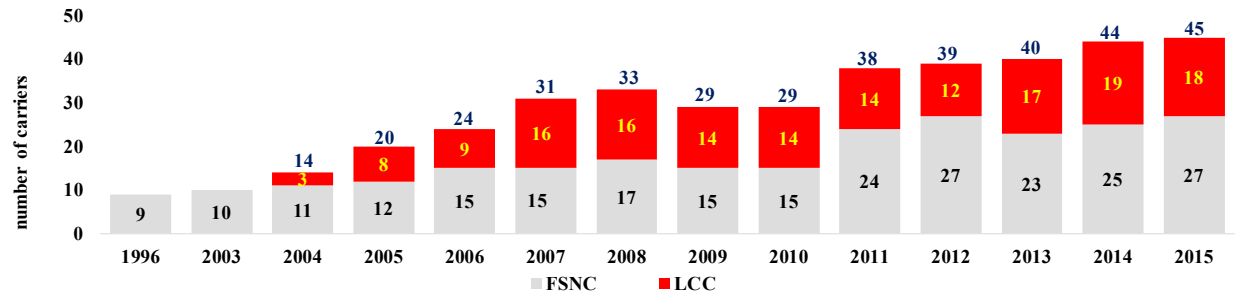

Fig. 4.

Number of Foreign Airline Competitors in Croatia by the Business Model in the Period 1996-2015 Source: Continuous authors research from the year 1996.

Dynamic changes of the airline entrance and in international scheduled traffic are very exits from the Croatian air transport market intensive after the year 2003:

- 1996

- 2003

- $2004-2015$

- $\quad 1996-2015$

- $1996-2015$

- 2015
9 competitors on the market;

10 competitors on the market;

57 new entrants on the market;

70 total competitors on the market (41 FSCN + 29 LCC);

25 competitors leave the market (14 FSCN + 11 LCC);

45 competitors on the market (27 FSCN + 18 LCC).

High degree of seasonality in demand on the in international traffic divided by foreigners Croatian aviation market by quarters of 2015 vs. Croatian citizens are shown in Fig.5. 


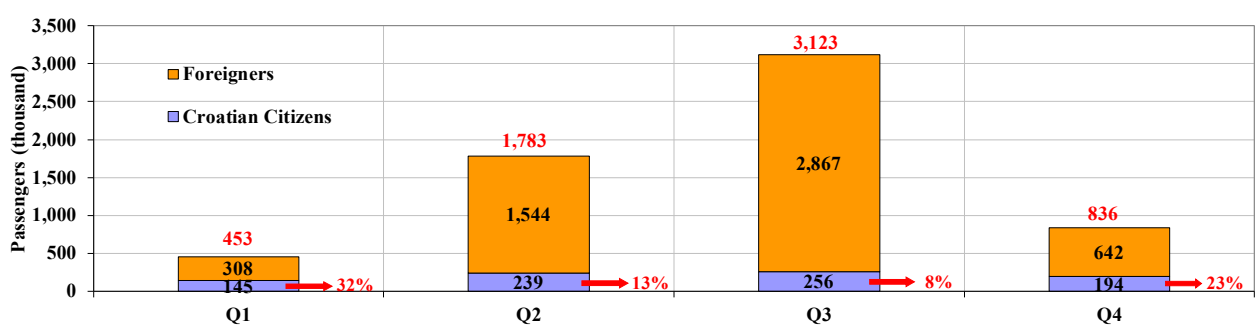

Fig. 5.

Passengers in International Air Traffic Divided by Foreigners vs. Croatian Citizens by the Quarters 2015 Source: Croatian Bureau of Statistics (2016a.), prepared by authors.

During the summer season on the Croatian market operates approximately 90 airlines and more than half of all passengers are transported in the third quarter, while in winter the presence of competition is minimal. Croatia Airlines is connecting Croatian regions throughout the whole year, which also allows Croatian airports year-round even during winter low demand.

\section{Table 8}

Top Ten FSNC Foreign Airlines Competitors on Croatian Air Transport Market in the Period 19962015 by International Scheduled Passengers

\begin{tabular}{|c|c|c|c|c|c|c|c|c|c|c|c|}
\hline Year & Lufthansa & $\begin{array}{c}\text { Austrian } \\
\text { Airlines }\end{array}$ & $\begin{array}{l}\text { British } \\
\text { Airways }\end{array}$ & SAS & Aeroflot & $\begin{array}{c}\text { Turkish } \\
\text { Airlines }\end{array}$ & $\begin{array}{c}\text { Air } \\
\text { France }\end{array}$ & $\begin{array}{l}\text { Czech } \\
\text { Airlines }\end{array}$ & Malev & $\begin{array}{c}\text { Swissair } \\
\text { / Swiss }\end{array}$ & Total \\
\hline 1996 & 97,736 & 29,077 & 0 & 9,136 & 9,176 & \begin{tabular}{|l|}
0 \\
\end{tabular} & 7,393 & \begin{tabular}{|r|}
27,095 \\
\end{tabular} & 0 & \begin{tabular}{|l|}
57,448 \\
\end{tabular} & 237,061 \\
\hline 1997 & 122,300 & 25,454 & 33,648 & 30,210 & 13,075 & 0 & 10,655 & 35,538 & $\overline{0}$ & 46,402 & 317,282 \\
\hline 1998 & 141,796 & 27,271 & 41,043 & 16,390 & 11,176 & 961 & 9,354 & 35,899 & 0 & 46,184 & 330,074 \\
\hline 1999 & 133,142 & 28,698 & 40,450 & 1,757 & 6,828 & 10,389 & 8,436 & 34,509 & 1,509 & 41,822 & 307,540 \\
\hline 2000 & 133,314 & 31,165 & 32,034 & 0 & 13,875 & 20,320 & 23,852 & 29,623 & 9,213 & 42,262 & 335,658 \\
\hline 2001 & 103,327 & 45,635 & 29,144 & 0 & 16,975 & 19,337 & 23,998 & 31,480 & 19,353 & 38,089 & 327,338 \\
\hline 2002 & 108,041 & 54,058 & 25,624 & 0 & 18,220 & 24,282 & 30,281 & 30,899 & 23,154 & 26,757 & 341,316 \\
\hline 2003 & 112,164 & 49,654 & 23,219 & 0 & 17,680 & 25,050 & 32,070 & 29,537 & 26,901 & 21,856 & 338,131 \\
\hline 2004 & 140,094 & 66,874 & 32,400 & 29,151 & 16,802 & 25,077 & 32,736 & 36,265 & 67,303 & 0 & 446,702 \\
\hline 2005 & 133,148 & 0,399 & 62,837 & 22,402 & 23,319 & 26,470 & 32,035 & 34,846 & 74,267 & 0 & 499,723 \\
\hline 2006 & 140,010 & 111,111 & 126,736 & 12,000 & 26,893 & 26,981 & 48,968 & 51,935 & 73,245 & 0 & 617,879 \\
\hline 2007 & 156,864 & 134,038 & 108,580 & 12,500 & 36,085 & 34,839 & 55,291 & 51,481 & 74,879 & 0 & 664,557 \\
\hline 2008 & 157,096 & 151,988 & 64,548 & 27,286 & 49,773 & 41,499 & 73,577 & 45,652 & 38,694 & 0 & 650,113 \\
\hline 2009 & 154,456 & 115,827 & 84,190 & 17,601 & 57,574 & 56,280 & 71,913 & 36,460 & 43,037 & 0 & 637,338 \\
\hline 2010 & 192,787 & 145,631 & 58,787 & 55,074 & 63,098 & 62,070 & 72,123 & 32,901 & 38,930 & & 721,401 \\
\hline 2011 & 230,914 & 181,983 & 61,550 & 74,269 & 109,520 & 63,596 & 78,676 & 21,327 & 45,808 & & 867,643 \\
\hline 2012 & 318,161 & 196,856 & 61,941 & 105,105 & 138,281 & 73,557 & 85,582 & 4,245 & 1,099 & & 984,827 \\
\hline 2013 & 382,822 & 193,411 & 127,291 & 162,651 & 105,514 & 98,262 & 62,200 & & & & $1,132,151$ \\
\hline 2014 & 323,063 & 194,204 & 139,373 & 201,550 & 102,657 & 147,267 & 55,955 & & & & $1,164,069$ \\
\hline 2015 & 343,225 & 199,095 & 154,447 & 185,048 & 74,790 & 146,930 & 60,014 & & & 35,264 & $1,198,813$ \\
\hline Total & \begin{tabular}{|l|}
$3,624,460$ \\
\end{tabular} & \begin{tabular}{|l|}
$2,072,429$ \\
\end{tabular} & \begin{tabular}{|l|}
$1,307,842$ \\
\end{tabular} & \begin{tabular}{|l|}
962,130 \\
\end{tabular} & 911,311 & \begin{tabular}{|c|}
903,167 \\
\end{tabular} & \begin{tabular}{|l|l|}
875,109 \\
\end{tabular} & 569,692 & 537,392 & 356,084 & $12,119,616$ \\
\hline AAGR & $6.8 \%$ & $10.7 \%$ & $8.8 \%$ & $17.2 \%$ & \begin{tabular}{|l|}
$11.7 \%$ \\
\end{tabular} & $18.0 \%$ & $11.7 \%$ & - & - & $-2.5 \%$ & $8.9 \%$ \\
\hline
\end{tabular}

Source: According (Bajić et al., 2014), Croatian Bureau of Statistics (2015, 2016b), Croatian airports statistics prepared by authors.

The individual results of the competition in the Croatian aviation market in international scheduled traffic for the period 1996-2015 indicate wining growth trends (Lufthansa, Turkish Airlines, Air France, British Airways, Aeroflot, Austrian 
and SAS) and losing trends (CSA, Swissair/ Swiss, Malev). Besides mentioned on the market where also present: Qatar, Iberia,
Alitalia, LOT, Adria Airways, JAT/ Air Serbia, Luxair, SN Brussels, BH Airlines, TAP, etc.

\section{Table 9}

Top Ten LCC Foreign Airlines Competitors on Croatian Air Transport Market in the Period 2004-2015 by International Scheduled Passengers

\begin{tabular}{|c|c|c|c|c|c|c|c|c|c|c|c|}
\hline Year & $\begin{array}{l}\text { German- } \\
\text { wings }\end{array}$ & easyJet & Ryanair & $\begin{array}{c}\text { Norwe- } \\
\text { gian }\end{array}$ & $\begin{array}{c}\text { Thomp- } \\
\text { sonfly }\end{array}$ & $\begin{array}{c}\text { Vueling / } \\
\text { Clickair }\end{array}$ & $\begin{array}{c}\text { HP Exp / } \\
\text { TUIfly }\end{array}$ & Wizz Air & Jet2Com & $\begin{array}{c}\text { Aer } \\
\text { Lingus }\end{array}$ & Total \\
\hline 2004 & 24,603 & 0 & 0 & 0 & 0 & \begin{tabular}{|l|}
0 \\
\end{tabular} & & 0 & & 10,000 & 34,603 \\
\hline 2005 & \begin{tabular}{|l|l|}
149,192 \\
\end{tabular} & 0 & 0 & 54,374 & 0 & 0 & 51,537 & 0 & & 23,589 & 278,692 \\
\hline 2006 & 239,666 & 47,587 & 5,521 & 91,347 & 0 & 0 & 113,431 & 75,110 & & 30,190 & 602,852 \\
\hline 2007 & 325,099 & 56,604 & 73,762 & 88,457 & \begin{tabular}{|l|l|}
$\mathbf{9 8 , 8 0 0}$ \\
\end{tabular} & 17,030 & 122,839 & 91,803 & & 31,490 & 905,884 \\
\hline 2008 & 404,506 & 68,706 & 62,900 & 128,571 & 78,396 & 45,482 & 118,335 & 51,047 & & 34,317 & 992,260 \\
\hline 2009 & 395,237 & 157,906 & 148,206 & 134,842 & & 23,722 & 123,100 & 48,132 & 11,836 & 31,653 & $1,074,634$ \\
\hline 2010 & 431,519 & 289,225 & 216,236 & 203,842 & 58,193 & 34,358 & & 75,578 & & 36,690 & $1,345,641$ \\
\hline 2011 & 398,100 & 383,882 & 266,303 & 159,535 & 62,870 & 39,660 & & 29,475 & 43,090 & 39,042 & $1,421,957$ \\
\hline 2012 & 367,997 & 410,465 & 316,402 & 172,403 & 64,576 & 64,478 & & 28,143 & 65,223 & 43,722 & $1,533,409$ \\
\hline 2013 & 425,920 & 426,353 & 503,790 & 255,506 & 72,101 & 73,469 & & 11,820 & 106,424 & 46,546 & $1,921,929$ \\
\hline 2014 & 499,860 & 489,980 & 465,396 & 286,038 & 74,282 & 145,926 & & 15,922 & 106,231 & 51,553 & $2,135,188$ \\
\hline 2015 & 494,009 & 595,242 & 394,753 & 339,835 & 154,464 & 198,355 & & 33,034 & 113,567 & 53,144 & $2,376,403$ \\
\hline Total & $4,155,708$ & \begin{tabular}{|l|}
$2,925,950$ \\
\end{tabular} & \begin{tabular}{|l|}
$2,453,269$ \\
\end{tabular} & \begin{tabular}{|l|}
$1,914,750$ \\
\end{tabular} & \begin{tabular}{|l|}
663,682 \\
\end{tabular} & \begin{tabular}{|l|}
642,480 \\
\end{tabular} & 529,242 & \begin{tabular}{|l|}
460,064 \\
\end{tabular} & \begin{tabular}{|l|}
446,371 \\
\end{tabular} & \begin{tabular}{|l|}
431,936 \\
\end{tabular} & $14,623,452$ \\
\hline AAGR & $12.7 \%$ & \begin{tabular}{|l|}
$32.4 \%$ \\
\end{tabular} & $23.3 \%$ & \begin{tabular}{|l|}
$20.1 \%$ \\
\end{tabular} & \begin{tabular}{|l|}
$5.7 \%$ \\
\end{tabular} & $35.9 \%$ & - & \begin{tabular}{|r|}
$-8.7 \%$ \\
\end{tabular} & $27.4 \%$ & $8.5 \%$ & $23.9 \%$ \\
\hline
\end{tabular}

Source: According (Bajić et al,. 2014), Croatian Bureau of Statistics (2015, 2016b), Croatian airports statistics prepared by authors.

From the Table 9 is visible strong dynamic rise and market share increase of low-cost carriers, especially Germanwings, easyJet, Ryanair and Norwegian (from two million passengers to more than four million passengers in the period). Average annual growth rate for the period 2005-2015 was impressive 23.9 percent, compared to 8.9 percent average annual growth rate of FSNC airlines in the period 1996-2015. In spite of such huge growth 11 LCC airlines leave Croatia market among them Sky Europe, Spanair, Cimber-Sterling, Flybe, etc.

In such competitive environment Croatia Airlines implemented a restructuring program according the European state aid rules. The implementation of restructuring measures and network strategy improvement generated a positive financial result in the period 2013 - 2015. Compensation and selfcontribution measures are in line with EU competition, restructuring and state aid rules (for more details Croatian Official Gazette 105/2013).

Specific important items additionally affecting Croatia Airlines business are:

- Seasonality. There is a certain improvement comparing the highest volume month (August) and lowest (February). Ratio changed from 1:3,1 to $1: 2.5$ at the period $2000-2015$.

- Average flight distance. One of the most important postulates of air transport economics is its correlation with the distance. Unit costs and yield per flight are lower when the distance is increasing. Average distance of Croatia Airlines flights in the year 2015 is only 634 kilometers, which is much shorter compared to the aviation industry standards. 
- Price elasticity and number of competitors. Price change affects the quantity of demand together with strongest competition in the Southeast Europe region significantly affect traffic and financial achievements.

- Living standard in Croatia. Average GDP per capita in the year 2015 is less than $50 \%$ below the EU-28 average.

- Interest burden. In the year 2000 interest rate of Croatia Airlines was $17 \%$ falling by the year 2015 to $0.7 \%$ which is very good news but for the whole period it was much higher compared to average interest burden of worldwide and AEA members (three to five times higher).

- Domestic scheduled traffic. With average fare level of 90 EUR per passenger in European domestic traffic PLF in Croatian domestic traffic would seriously fall from achieved $67.3 \%$ (average one-way ticket fare is less than 38 EUR). In order to maintain appropriate scheduled air services on routes which are vital for the economic development of the region Croatia implemented public service obligation model according to the European Union legislation.

\section{Conclusions}

Global air transport growth in spite of permanent competition challenges on the market has remained strong due to various initiatives and activities concerning:

- Cost structure optimization and unit cost reduction;

- "e-Commerce" digitalization for improvement connections with customers e.g. website, mobile technology, personalization;
- Revenue improvements and ancillary revenue maximization;

- Improvement of all labor, aircraft and fuel productivity indicators;

- Market expansion and cooperation through alliances, interlining, code sharing, franchising, mergers and acquisitions;

- Enhancing customer loyalty, reward and frequent flyer programs;

- Capacity management improvements through aircraft acquisition (ownership or leasing).

On European market high-speed trains and modern highways increasingly compete with air transport. Southeast Europe region is characterized by relatively low level of air connectivity within the region.

The liberalization of the Croatian aviation market significantly influenced the increase of competition and demand in the international scheduled passenger traffic. Regression analysis confirms that the changes of Croatian gross domestic product and economic difficulties affecting the level of demand and the level of air transport results concerning Croatian citizens. Croatia Airlines face a hugest competition increase in the Southeast Europe region. Market share of Croatia Airlines dropped from 59 percent in the year 2003 to only 28 percent in the year 2015 .

In such competitive environment Croatia Airlines implemented a restructuring program according the European state aid rules. Analysis of airline competition in Croatia indicates that the restructuring process of Croatia Airlines should be continued toward improvement the efficiency of the business model as a necessary precondition for sustainable business in the future. 


\section{References}

Abeyratne, R. 2016. Competition and Investment in Air Transport. Springer International, Switzerland. 239 p.

anna.aero. 2016. European Airport Traffic Trends, Available from internet: < http://www.anna.aero/ databases/>. (22.12.2016.).

ATAG. 2016. Aviation Benefits Beyond Borders. Air Transport Action Group, Switzerland. 80 p.

Bajić, J.; Mišetić, I.; Tatalović, M. 2016. Southeast Europe Air Transport in the Light of Global Market Changes - Challenges For Croatia. In book (ed. Kandžija, V., Kumar, A.), Economic Integrations, Competition and Cooperation. CEMAFI International, Croatia: 249-273.

Bajić, J.; Tatalović, M.; Kučko, K. 2014. Analysis of Airline Competition in Croatia (in Croatian: Analiza zrakoplovne konkurencije u Hrvatskoj), Suvremeni promet 34(1-2): 178-186.

Baroux J.L. 2013. The Airlines: The Failure of an Industry. LID Publishing, USA. 224 p.

Bjelicic, B. 2013. Low Cost Carriers in Eastern Europe. In book (ed. Gross, S., Luck, M.) The Low Cost Carrier Worldwide, Ashgate, United Kingdom: 39-58.

Black, K. 2010. Business Statistics: For Contemporary Decision Making. Sixth Edition, Willey, USA. 864 p.

Capstats.com. 2015. Global Capacity Report, December 2015. Available from internet: < http://capstats.com/ Capacity Reports. aspx\#2015>. (10.1.2017.).

Clark, P. 2010. Stormy Skies - Airlines in Crises. Ashgate, UK. 178 p.

Croatian Bureau of Statistics. 2010. Tourism, 2009. Available from internet: < http://www.dzs.hr/Hrv Eng/publication /2010/SI-1408.pdf >. (11.9.2011.).
Croatian Bureau of Statistics. 2014. Tourism, 2013. Available from internet: < http://www.dzs.hr/Hrv Eng/publication /2014/SI-1515.pdf >. (11.2.2017.).

Croatian Bureau of Statistics. 2015. Statistical Yearbook of the Republic of Croatia 2015. Croatia.

Croatian Bureau of Statistics. 2016a. First release Number: 5.1.5/11. Available from internet: < http:// www.dzs.hr/>. (10.1.2017.).

Croatian Bureau of Statistics. 2016b. Statistical Yearbook of the Republic of Croatia 2016. Croatia.

Croatian Bureau of Statistics. 2016c. Tourism, 2015. Available from internet: < http://www.dzs.hr/Hrv Eng/publication /2016, /SI-1564.pdf/>. (11.2.2017.).

Dizikes, P.; Valenti, C. 2001. Airline Bailout: How Big, How Crucial? Available from internet: < / story? $\mathrm{id}=87677 \&$ page $=1>$. $(10.5 .2016$. $)$.

Doganis, R. 2010. Flying off Course - Airline economics and marketing. Fourth edition, Routledge, United Kingdom. 352 p.

Gittell, J.H. et al. 2016. Labor Relations and Human Resource Management in the Airline Industry. In book (ed.Belobaba, P. P.et al.) The Global Airline Industry, Wiley, USA: 287-325.

Heshmati, A.; Kim, J. 2016. Efficiency and Competitiveness of International Airlines. Springer, Singapore. 192 p.

Henke, M. 2016. Airline e-Commerce Log on. Take off. Routledge, United Kingdom. 610 p.

HGK. 2016. Economic Trends (in Croatian: Gospodarska kretanja) 11/12 2016. Hrvatska gospodarska komora (Croatian Chamber of Economy), Croatia.

Hill, C.V.L.; Jones, G.R.; Schilling, M.A. 2015. Strategic Management Theory. $11^{\text {th }}$ Edition, Cengage Learning, USA. 528 p. 
IATA. 2014. Financial Forecast Archives, Available from internet: <http://www.iata.org/publications/ economics/Pages/ ffarchives.aspx>. (10.1.2017.).

IATA. 2016. Industry Economic Performance, Available from internet: < http://www.iata.org/publications/economics / Pages /industry-performance.asp $\underline{x}>$. (10.1.2017.).

ICAO. 2013. Global Air Transport Outlook to 2030 and trends to 2040. International Civil Aviation Organization, Canada. $156 \mathrm{p}$.

IdeaWorksCompany. 2016a. 2015 Top 10 Ancillary Revenue Rankings, Available from internet: <>. (17.1.2017.).

IdeaWorksCompany. 2016b. Press-Release-115-GlobalEstimate, Available from internet: <>. (17.1.2017.).

Janjic, M. 2007. The Sustainability of Air Transportation: A Quantitative Analysis and Assessment. Ashgate, United Kingdom. 376.p.

Mayer-Shonberger, V.; Cukier, K. 2014. Big Data: A Revolution That Will Transform How We Live, Work, and Think. Houghton Mifflin Harcourt, USA. 272 p.

McGrath, R.G. 2013. The End of Competitive Advantage: How to Keep Your Strategy Moving as Fast as Your Business. Harvard Business Review Press, USA. 240 p.

Mišetić, I.; Tatalović, M.; Malović-Beganović, I. 2007. Competition on Croatian Air Traffic Market (in Croatian: Konkurencija na hrvatskom zrakoplovnom tržištu), Suvremeni promet 27(6): 601-609.

Palling, C.; Hooper, P.; Thomas, C. 2014. The Sustainability in Air Transport. In book (ed. Goetz, A.R., Budd, L.) Geographies of Air Transport. Ashgate, United Kingdom: 125-140.

Pearce, B. 2013. Profitability and the Air Transport Value Chain. International Air Transport Association, Switzerland. $52 \mathrm{p}$.
Pilarski, A. 2007. Why Can't We Make Money in Aviation? Ashgate, United Kingdom. 260 p.

Porter, M. E. 2007. Competitive Advantage (in Croatian: Konkurentska prednost). Masmedija, Croatia. 489 p.

Shaw, S. 2011. Airline Marketing and Management. Seventh Edition. Ashgate, United Kingdom. 378 p.

Steiner, S.; Tatalović, M.; Bajić, J. 2010. Competition and Cooperation on European Southeast Air Transport Market. In book (ed. Kandžija, V., Kumar, A.) Economic integrations, competition and cooperation. University of Rijeka, Faculty of Economics, Croatia: 534-552.

Sull, D.N. 2005. Why Good Companies Go Bad and how Great Managers Remake Them. Harvard Business Press, USA. 288 p.

Taneja, N.K. 2016a. Designing Future-Oriented Airline Businesses. Routledge, United Kingdom. 308 p.

Taneja, N.K. 2016b. Extending the Boundary of the Airline Business Airline Leader 36: 8-11.

Taneja, N.K. 2017. Airline Industry: Poised for Disruptive Innovation? Routledge, United Kingdom. 322 p.

Tatalović, M.; Bajić, J.; Šimunović, S. 2014. Fitting the Fleet and the Service to the SEE Market Demand - Future of Small European Airlines. In book (ed. Kandžija, V., Kumar, A.) Economic integrations, competition and cooperation. University of Rijeka, Faculty of Economics, Croatia: 296-309.

Tatalović, M.; Bajić, J.; Šimunović, S. 2012a. Air Transport Development in Croatia: Strategy without Strategy (in Croatian: Razvoj zračnog prometa u Hrvatskoj: Strategija bez strategije), Suvremeni promet 31(1-2): 11-21.

Tatalović, M.; Mišetić, I.; Bajić, J. 2012b. Airline Management (in Croatian: Menadžment zrakoplovne kompanije). Mate d.o.o. Croatia. 891 p. 
Truxsal, S. 2013. Competition and Regulation in the Airline Industry: Puppets in Chaos. Routledge, United Kingdom. 208 p.

UNWTO. 2016. Tourism Highlights. 2016 Edition. The World Tourism Organization, Spain.

WEF. 2013. The Travel \& Tourism Competitiveness Report 2013: Reducing Barriers to Economic Growth and Job Creation. World Economic Forum, Switzerland. 485 p.

WEF. 2015. The Travel \& Tourism Competitiveness Report 2015: Growth through Shocks. World Economic Forum, Switzerland. 509 p.
WEF. 2016. The Global Competitiveness Report 2016-2017. World Economic Forum, Switzerland. 383 p.

Whish, R.; Bailey, D. 2012. Competition Law. Seventh Edition. Oxford University Press, USA. 1015 p.

Whyte, R.; Lohmann, G. 2017. Airline Business Model. In book (ed. Budd, L., Ison, S.) Air Transport Management An International Perspective. Routlage, United Kingdom: 107-121.

www.tuzla-airport.ba, 2017. Statistics for passenger traffic (passengers). Available from internet: < http:// www.tuzla-airport.ba/en/statistika/>. (28.2.2017.). 